\title{
Political Law, Legalistic Politics: A Recent History of the Political Question Doctrine
}

\author{
Robert F. Nagel $\dagger$
}

The phrase "political question doctrine" seems innocuous. This is partly because of familiarity. It is also because the three words are lined up in a reassuring sequence. Although "political" has unruly and unsavory connotations, it is followed by the tame "question." The phrase is concerned, not with political power or political dilemmas or political passions, but with those political issues that come rounded to an intellectual point, that are shaped into questions. And the last word, "doctrine," removes whatever sting remains. Suggestive of rules, predictability, and stodgy formalism, "doctrine" assimilates the political into the legal. In the brief space of three words, the phrase "political question doctrine" funnels the noisy sounds of conflict into a staid category of law; it collapses the wide world-where aspirations, hatreds, and interests are in collision-into a small, identifiable arena. The boundaries to this arena mark the limits of the judicial function, but even as courts acknowledge the political, they subordinate it. To have a doctrine that defines where political decision making is appropriate, after all, is only to make an exception to a norm of judicial sovereignty over the fundamental issues called "constitutional."

My theme is that the political question doctrine is not innocuous. Like many dangerous things, it has been given a safe appearance and name. But what looks like a slight crack is a fault line. This doctrine, so frequently criticized and discounted, nevertheless has a tenacious hold on our jurisprudence. After two hundred years of growth and consolidation, the nation's judicial system is an imposing edifice built over a break that looks small but does not go away. Indeed, it is worth tracing some of the ways that jurists and scholars have minimized the "doctrine" of political questions because that idea turns out to be more subversive even as it is dismissed with greater certainty.

$\dagger$ Rothgerber Professor of Constitutional Law, University of Colorado School of Law. Some of the work on this essay was done while the author was Lee Visiting Professor at the Institute of Bill of Rights Law, Marshall-Wythe School of Law. Professor Steven D. Smith and Judge Stephen F. Williams contributed useful comments on a preliminary draft. 
The distinction in constitutional law between political and legal questions has been with us from the beginning. It was discussed in Marbury $v$ Madison ${ }^{1}$ and was emphasized in numerous cases during the 19th century. ${ }^{2}$ At least one scholar has traced its antecedents into antiquity. ${ }^{3}$ By 1924 , Oliver Field could state simply, "It is elementary that the courts will not decide political questions." With the calm intensity of a birdwatcher, Field observed the behavior of the courts and noted the results:

-The date at which a war begins is a political question.

-The courts will not decide on the wisdom of any particular policy adopted by Congress regarding the control of aliens.

-Whenever the political departments assert title to or jurisdiction over territory, the courts must acquiesce in that assertion.

-Whether a state constitution or amendments to the same have been adopted in a proper manner will not be settled by the federal courts.

-The federal courts will not inquire into the constitutional powers of the representatives of foreign nations with whom the United States negotiates treaties. ${ }^{5}$

And so on. For Field, the political question doctrine, like any other legal doctrine, was a matter for observation, description, and rationalization. Dozens of cases could be cited to show that in discrete classes of constitutional issues, relevant rules were lacking and that these issues were treated as at least partial exceptions to the power of judicial review. ${ }^{6}$ Categories of lawlessness could be listed as easily as could the maxims of equity.

If Field's approach to political questions seems naive and old fashioned, consider that it influenced the 1953 edition of Hart and Wechsler's monumental The Federal Courts and the Federal System. ${ }^{7}$ Here, too, scholars could list areas in which the applicability of the political question doctrine seemed reasonably settled. These

15 US (1 Cranch) 137, 164 (1803).

2 See Oliver P. Field, The Doctrine of Political Questions in the Federal Courts, 8 Minn L Rev 485 (1924).

3 Maurice Finkelstein, Judicial Self-Limitation, 37 Harv L Rev 338 (1924).

- Field, 8 Minn L Rev at 485 (cited in note 2).

- Id at 486-509.

- Id at 511-12.

' Henry M. Hart, Jr. and Herbert Wechsler, The Federal Courts and the Federal System (Foundation, 1953). 
were:

(1) Republican form of government,

(2) Enactment of statutes,

(3) Constitutional enactment,

(4) Duration of state of war,

(5) International boundaries,

(6) Abrogation of treaties,

(7) Recognition of foreign governments, and

(8) Other matters affecting foreign policy. ${ }^{8}$

It is a sign of how far attitudes have changed in a few decades that the main case under "Political Questions" in the 1953 edition is Colegrove $v$ Green, in which the Court said matter-of-factly: "Of course no court can affirmatively remap the Illinois districts. . . . At best we could only declare the existing electoral system invalid."9

In 1953 there were, however, subtle signs of the coming disintegration of a formally legalistic conception of political questions. Hart and Wechsler's text emphasizes "the great variety of considerations" that might contribute to the conclusion that an issue should be decided by a political department. ${ }^{10}$ Consistently with Field's descriptive analysis, some of these considerations relate to the unavailability of principles on which cases could be decided. But others depend upon the exercise of standardless, political judgment by the courts themselves. There is a reference, for instance, to the possibility that courts might not be able "to deal with the possible consequences of decision." "Here is the telltale influence of academic thinkers like Maurice Finkelstein, who proposed in preliminary form many of the ideas that Alexander Bickel would later propound with shattering effect. ${ }^{12}$ Overall, however, in 1953 the political question doctrine was still a small fissure-an odd sort of legal doctrine but a doctrine nonetheless.

By 1973, when the second edition of Hart and Wechsler's The Federal Courts and the Federal System ${ }^{13}$ was published, this older conceptualization of political questions was transformed through the lens of modern functionalism. The authors replaced both their

- Id at 192-96.

- Id at 199, quoting Colegrove v Green, 328 US 549 (1946).

10 Id at 192, 207.

11 Id at 192.

12 Finkelstein, 37 Harv L Rev 338 (cited in note 3). Alexander M. Bickel, The Least Dangerous Branch: The Supreme Court at the Bar of Politics (Yale, 1962).

1s Paul M. Bator, et al, Hart and Wechsler's The Federal Courts and the Federal System (Foundation, 2d ed 1973). 
text, which had itemized categories of political questions, and the excerpt from Colegrove $v$ Green, with its innocent assumptions about the nature of the judicial function, with Baker $v$ Carr. ${ }^{14}$ The Court's opinion in Baker listed categories of political questions, but not for the purpose of naturalistic description. A close look at each class of political question cases revealed a moral, a purpose to be served by non-justiciability. These functional justifications, collected and summarized in handy form, were to be the "law" of the political question doctrine:

It is apparent that several formulations which vary slightly according to the settings in which the questions arise may describe a political question, although each has one or more elements which identify it as essentially a function of the separation of powers. Prominent on the surface of any case held to involve a political question is found a textually demonstrable constitutional commitment of the issue to a coordinate political department; or a lack of judicially discoverable and manageable standards for resolving it; or the impossibility of deciding without an initial policy determination of a kind clearly for nonjudicial discretion; or the impossibility of a court's undertaking independent resolution without expressing lack of the respect due coordinate branches of government; or an unusual need for unquestioning adherence to a political decision already made; or the potentiality of embarrassment from multifarious pronouncements by various departments on one question.

Unless one of these formulations is inextricable from the case at bar, there should be no dismissal for non-justiciability $\ldots .^{15}$

The Court's rejection of "semantic cataloguing"16 made a pleasant sound in the modern ear. Moreover, both the general tone of Baker and its specific holding suggested that functional analysis would present no general threat to judicial power. Indeed, the implicit understanding was that application of the Baker "formulations" through "discriminating inquiry" would narrow the scope of political question doctrine. ${ }^{17}$

In this respect, Baker replaced the old fashioned innocence of

\footnotetext{
369 US 186 (1962).

${ }^{15}$ Id at 220.

18 Id.

17 Id.
} 
Colegrove with a modern naivete. After the imaginative interpretations of constitutional text prior to Baker, why assume that the search for a "textually demonstrable commitment [to a nonjudicial branch]" would be containable? Or that "judicially manageable standards" exist in any of the significant areas controlled by constitutional doctrine? Or that judicial review does not often-or perhaps even always-express "lack of respect" for the other branches of government? Replacement of formal categories with functional considerations was accompanied by a guileless belief that such realism would not narrow or undermine the judicial function.

On the contrary, the notes following Baker $v$ Carr in the second edition of Hart and Wechsler suggest that functionalism might lead to an expansion of the judiciary's role. This possibility was consistent, not only with the Court's willingness to enter the political thicket of apportionment, but also with its later decision in Powell $v$ McCormack that a congressional determination of the qualifications of a member under Article I, section 5 presented a justiciable controversy. ${ }^{18}$ The editors of Hart and Wechsler captured the common reaction to Powell by noting that simple textual analysis could not have resolved the "textually demonstrable commitment" issue and by questioning the adequacy of the Court's treatment of the other Baker criteria. ${ }^{18}$ The authors suggest what many thought after Baker and Powell-that it was the political question doctrine, not judicial power, that was in jeopardy. ${ }^{20}$ "Is there any constitutional issue," they ask, "to which [the Powell Court's] reasoning would not apply?"21

The Baker "formulations," then, came clothed as law in the modern fashion-multiple factors that in varying combinations could be made to serve sophisticated policies. As with any legal standard, there was thought to be the danger of unprincipled or specious application. But for the most part, the second edition of Hart and Wechsler accepts the innocent appearances of the Baker opinion and treats the political question doctrine as simply another doctrine. Recognition of the practical and potentially lawless content of the Baker "considerations," however, could not entirely be suppressed, if for no other reason than that The Least Danger-

18 395 US 486 (1969).

19 Bator, et al, The Federal Courts (2d ed) at 235 (cited in note 13).

${ }^{20}$ For some early reactions to Powell, see Comments on Powell v. McCormack, 17 UCLA L Rev 58 (1969).

${ }^{21}$ Bator, et al, The Federal Courts (2d ed) at 235 (cited in note 13). 
ous Branch had been published in $1962 .{ }^{22}$ At the end of the section on "Political Questions," the second edition of Hart and Wechsler quotes two disturbing paragraphs from Alexander Bickel:

[O]nly by means of a play on words can the broad discretion that the courts have in fact exercised be turned into an act of constitutional interpretation governed by the general standards of the interpretive process. The political-question doctrine simply resists being domesticated in this fashion. There is ... something different about it, in kind not in degree; something greatly more flexible, something of prudence, not construction and not principle. And it is something that cannot exist within the four corners of Marbury v. Madison. . . . ... Such is the foundation, in both intellect and instinct, of the political-question doctrine: the Court's sense of lack of capacity, compounded in unequal parts of (a) the strangeness of the issue and its intractability to principled resolution; (b) the sheer momentousness of it, which tends to unbalance judicial judgment; (c) the anxiety, not so much that the judicial judgment will be ignored, as that perhaps it should but will not be; (d) finally ("in a mature democracy"), the inner vulnerability, the self-doubt of an institution which is electorally irresponsible and has no earth to draw strength from. ${ }^{23}$

Can it be true that the proper exercise of the federal judicial function presupposes that judges begin by making deeply political judgments? Does the rule of law rest so transparently on nonlegal foundations? Such questions did work their way into the second edition, but Bickel's words are sandwiched between a stern quote from Herbert Wechsler and a long series of skeptical questions. The quote that precedes Bickel intones:

[A]ll the [political question] doctrine can defensibly imply is that the courts are called upon to judge whether the Constitution has committed to another agency ... the autonomous determination of the issue raised, a finding that itself requires an interpretation .... to be made and judged by standards that should govern the interpretive process generally. ${ }^{24}$

The page of questions that follows the Bickel passage begins with

22 Bickel, The Least Dangerous Branch (cited in note 12).

${ }^{23}$ Bator, et al, The Federal Courts (2d ed) at 240, quoting Bickel, The Least Dangerous Branch at 125-26, 184 (cited in note 12).

${ }^{24}$ Id, quoting Herbert Wechsler, Principles, Politics and Fundamental Law 11-14 (Harvard, 1961). 
this salvo:

What is the warrant for the "broad discretion" Professor Bickel would attribute to the courts? If it is not authorized by the Constitution, what is its source? Is it an acceptable general premise that courts are not obligated to decide issues in cases properly before them if they choose not to do so? ${ }^{25}$

Plainly, in 1973 it was thought important to hammer shut the gap that Bickel had pried open. Fifteen years later calm has been restored, at least if the 1988 edition of Hart and Wechsler ${ }^{26}$ is an accurate reflection of the present state of academic and judicial thinking on political questions. The most recent edition does contrast the Wechsler and Bickel positions but eliminates the drumbeat of questions. ${ }^{27}$ More importantly, new materials incorporated into the third edition largely support the view that since 1973, the political question doctrine has been laid to rest. The authors now refer readers to Louis Henkin's influential argument that no case need be read as actually having applied the political question doctrine and to Martin Redish's self-assured polemic against the wisdom of ever applying it. ${ }^{28}$ While academics had been wondering whether the political question doctrine ever existed and had been insisting that it should not exist, the Court continued building on Baker v Carr and Powell v McCormack. The third edition points out that in Goldwater $v$ Carter, five justices could not be found to support the proposition that the President's authority to terminate a treaty presented a political question. ${ }^{28}$ It refers briefly to Davis $v$ Bandemer, in which the Court rejected an argument that political gerrymandering of legislative districts involved a political question..$^{30}$ And, of course, the reader also learns of United States $v$ Nixon and INS $v$ Chadha, in which the Court emphatically repudiated the notion that the principle of separation of powers is nonjusticiable. ${ }^{31}$ Although it was not possible in 1988 to conclude that

25 Id.

${ }^{26}$ Paul M. Bator, et al, Hart and Wechsler's The Federal Courts and the Federal System (Foundation, 3d ed 1988).

27 Id at $293-94$.

${ }^{28}$ Id at $288 \mathrm{n} \mathrm{1}$, citing Louis Henkin, Is There a "Political Question" Doctrine? 85 Yale L J 597 (1976); Martin H. Redish, Judicial Review and the "Political Question", 79 Nw U L Rev 1031 (1984-85).

29 Id at 290-91, citing Goldwater v Carter, 444 US 996 (1979).

so Id at 292, citing Davis $V$ Bandemer, 478 US 109 (1986).

s1 Id at 289 n 3, citing United States $v$ Nixon, 418 US 683 (1974); INS v Chadha, 462 US 919 (1983). 
the political question doctrine was entirely gone ${ }^{32}$ its significance was small and declining. Bickel's ideas, therefore, were interesting enough to mention but were no longer threatening.

The irony is that in the same few years that separate the second and third editions of Hart and Wechsler, the role of the federal courts in managing public institutions and public policy had grown significantly. It is possible, then, that an intensely legalistic rejection of Bickel's advocacy of limited political judging helped to pave the way for a highly political role for the federal judiciary. In any case, between 1973 and 1988, Bickel's ideas on political questions lost much of their immediacy and force. To understand this change, it is necessary to look more closely at why Bickel's writings were at first so troubling.

II.

The initial debate spawned by Bickel had been remarkable in its tone and intensity. Both Herbert Wechsler and Gerald Gunther wrote with evident respect for Bickel and with an almost solemn sense of occasion. ${ }^{33}$ They shared with him a profound regard for the judiciary and for principled decision making. Their criticisms emerged from this common ground, and the force of those criticisms derived from the sense that principle was both intrinsic to the judicial function and valuable in its own right. Bickel thought that discretionary avoidance devices-preeminently the political question doctrine-were important for preserving the judiciary and the timely announcement of principle, but Wechsler and Gunther accused Bickel of abandoning the ideal of lawfulness. "Ultimately," wrote Gunther, "it is Bickel's starting point-his rigorous insistence that constitutional adjudication must be truly principled ... that proves to be [his] undoing." ${ }^{34}$ Wechsler claimed that Bickel's approach would "divorce the Court entirely from the text that it interprets and ... equate completely what is constitutional and what is good."3s

${ }^{32}$ Hart and Wechsler refers, for example, to Jesse Choper's writings, which influenced the Court's withdrawal from enforcing the Tenth Amendment in Garcia v San Antonio Metro. Transit Auth., 469 US 528 (1985). Bator, et al, The Federal Courts (3d ed) at 289 n 4 (cited in note 26 ). The notes also suggest that the amendment process may be nonjusticiable. Id at 290 .

ss Herbert Wechsler, Book Review, 75 Yale L J 672 (1966); Gerald Gunther, The Subtle Vices of the "Passive Virtues": A Comment on Principle and Expediency in Judicial Review, 64 Colum L Rev 1 (1964).

34 Gunther, 64 Colum L Rev at 24 (cited in note 33).

ss Wechsler, 75 Yale L J at 674 (cited in note 33). 
The accusation was that Bickel, in an effort to preserve the integrity of law, had abandoned lawfulness. This was a strong criticism but, by itself, it hardly justified the portentous quality of the debate. It was, after all, as much a description as a criticism. Moreover, the apparent locus of the argument was a relatively minor, preliminary matter. Neither Wechsler nor Gunther insisted that the Court had to reach the merits of all constitutional cases. They argued only that the decision whether to reach the merits had to be made in a principled way. Thus, their disagreement with Bickel was about whether a court could ever, even at the stage of deciding whether it should hear a case, take into account unprincipled political considerations.

The analogous issue today arises at the remedial stage of a lawsuit. May a lower court, in fashioning a remedy for school segregation, take into account the possibility that "white flight" might increase as a consequence of mandated busing? May a court, in designing a program of reform for substandard prisons, consider the possibility of staff resistance? Political discretion either at the beginning or the end of a lawsuit raises important questions, but these questions relate only partially and ambiguously to the integrity of the rule of law in the middle of the lawsuit. ${ }^{36}$ It is hardly imaginable that anyone would argue that a remedy must in all respects be designed without regard to practicality or institutional context. ${ }^{37}$ Similarly, in the 1960's it must have been perfectly clear that some political repercussions-a civil war or a crippled economy-are so important that courts can consider them in the preliminary stages of decision making without putting in doubt any of the premises behind judicial review. Yet the attack on Bickel's ideas was propounded in the significant and stately tones that customarily accompany scholarly concern about the rule of law itself.

All this gravity was not, I think, misplaced. Bickel's critics were correct to see in his position at least the beginnings of a radical attack on the role of principle in constitutional law. The problem with Bickel was not that he allowed some small place for politics at one stage of adjudication. The problem was that he gave disquieting reasons both for allowing some political discretion and for preserving a large role for principle.

so See, for example, Owen M. Fiss, The Supreme Court 1978 Term-Foreword: The Forms of Justice, 93 Harv L Rev 1 (1979).

${ }^{37}$ A proposal for some constraints on federal injunctions can be found in Robert $F$. Nagel, Separation of Powers and the Scope of Federal Equitable Remedies, 30 Stan L Rev 661 (1978). 
Although Bickel expressed a visceral distaste for "dogmatic, arbitrary, irrational [demands],"38 he understood that self-interest and political acceptability-popular reaction to concrete experience with programs and policies-properly affect judicial decisions. ${ }^{39} \mathrm{He}$ did not mean that a court's articulation of principle should be compromised or expedient, but that the proper conceptualization of principle requires that judges take experience into account. For Bickel, the criterion of principled adjudication was essential but also dangerous. It was a partial and inadequate source of constitutional meaning. " $[\mathrm{P}]$ rinciple is evolved conversationally not perfected unilaterally." 40 Thus, delay and avoidance were not technical devices at the margin of the judicial function. They were methods by which the error of abstraction could be prevented, and they went to the core of the judicial task.

The larger implications of Bickel's position could be found in the parallel between his argument and that of James Thayer, who years earlier had taken the small step from recognizing that politics properly affects constitutional content to concluding that the courts should play a relatively slight role in enforcement. ${ }^{41}$ Bickel emphasized principled reasoning and Thayer focused on the "academic treatment of [legal] texts," but both identified some basic aspect of the judicial function that excluded a "wide margin of considerations" relevant to constitutional meaning. ${ }^{42}$ Thayer's solution to the danger of over-judicialized constitutional meaning was not to carve out a small arena of "political" questions while leaving the rest to legalistic criteria. His solution, instead, was to carve out a small arena for the courts (through "the clear error rule") while treating the bulk of constitutional matters as political. ${ }^{43}$ Despite Bickel's starting point in apparently technical and

${ }^{38}$ Alexander M. Bickel, The Supreme Court and the Idea of Progress 82 (Harper \& Row, 1970). See also Bickel, The Least Dangerous Branch at 132-33 (cited in note 12).

${ }^{38}$ Bickel, The Least Dangerous Branch at 192-93, 244, 254, 258-59 (cited in note 12). This aspect of Bickel's thinking only gradually became clear. See Bickel, The Supreme Court and the Idea of Progress at 99, 175 (cited in note 38). For an account of the development and underlying coherence of Bickel's ideas, see Anthony T. Kronman, Alexander Bickel's Philosophy of Prudence, 94 Yale L J 1567 (1985).

40 Bickel, The Least Dangerous Branch at 244 (cited in note 12).

42 James B. Thayer, The Origin and Scope of the American Doctrine of Constitutional Law, 7 Harv L Rev 129 (1893).

42 Id at 138, 135.

4 Thayer argued that a court cannot disregard a statute "merely because it is concluded that upon a just and true construction the law is unconstitutional." Id at 144. To justify invalidation, the legislature must have made an error "so clear that it is not open to rational question." Id. Under this standard, courts should enforce any rational law wherever the Constitution "admits of different interpretations [or involves] a range of choice and 
exceptional avoidance devices, it is clear by the end of The Least Dangerous Branch that a passive stance-even in the face of massive resistance to school desegregation-was for Bickel also an integral part of the evolution of constitutional principle. ${ }^{44}$ Bickel was profoundly ambivalent in his assessment of principled decision making, but his critics were correct to sense in his ambivalence a potential for broad subordination of the legal to the political.

If it is true that Bickel undermined a legalistic conception of the judicial function partly because he feared the consequences of principled thinking, it is also true, paradoxically, that he insisted on a politicized function for the Court partly to preserve the quality of lawfulness. He admired what he feared, and it is clear that he intended the exercise of political discretion on avoidance issues to protect the prestige and integrity of the judiciary and its vital role in the enunciation of principle. But for what reason did Bickel want to preserve a place for principle? For him, principles were uncompromised goals, and their value lay in their clarity. He saw the function of the judiciary not so much as to dispense justice as to educate-to hold out unblemished ideals that otherwise might be lost in a political world where imperfection and expedience are brute facts. ${ }^{45}$ Since Bickel's devotion to principle was itself subordinate to the overarching purpose of enlightening public discourse, the primacy of the political in his approach to constitutional law was almost complete. He thought that politics should inform the content of constitutional law and that the function of judicial review was to inform politics.

Early critics of Bickel were right, then, to sense in his writing a fundamental challenge to the autonomy of judicial review and to the importance of legalistic criteria. The way he made a virtue of avoidance was a significant threat to a non-political theory of constitutional law that still seemed plausible and even compelling. In the decade and a half since the publication of the second edition of Hart and Wechsler, Bickel's ideas have become less threatening because in that brief time we have lost any distinctive sense of legality in public law. This loss is reflected in the substance and tone of current criticisms of the political question doctrine.

judgment ...." Id.

" Bickel, The Least Dangerous Branch at 258-59, 264-65 (cited in note 12).

(s) Id at 26, 68, 141, 240, 261, 268. 
III.

The commentary on the political question doctrine was once earnest and curious, as if studious observation could be counted on to assimilate the phenomenon to legal norms. Later, the tone of Bickel's work, as well as that of his critics, was weighty and foreboding, as if the doctrine opened long, troubling perspectives. Now the commentary tends to be impatient and adversarial, as if the issue were tedious rather than important; it ought at last, says much of the recent scholarship, ${ }^{46}$ to be made to go away.

Henkin, for instance, argues that some "political question" cases rest on a substantive legal conclusion that the relevant decision makers acted within their constitutional authority. Others rest on the conclusion that the decision makers did not transgress any constitutional limitations or prohibitions. Others involve normal kinds of doctrines like judicial deference and equitable discretion. In short, Henkin's position is that all the political question cases can be read as instances of constitutional interpretation. ${ }^{47}$ Since Henkin claims no more than that the cases can be read this way, and since his reading requires us to ignore or discount some of the Court's language, the larger issue is why Henkin so insistently wants to eliminate the political question doctrine. The advantage cannot be in insulating judicial decisions from political expedience, for principled decision making is undermined directly by political discretion that influences substantive interpretation of the Constitution. Moreover, since relief is denied under either the political question explanation or under Henkin's explanations, the advantage cannot be that substantive interpretation necessarily leads to the realization of constitutional ideals. Henkin's answer is that only the political question rationale carves out "an exception to Marbury."48 Reaching the merits at least requires the courts "to

t8 See Louis Henkin, Is There a "Political Question" Doctrine? 85 Yale L J 597 (1976); Martin H. Redish, Judicial Review and the "Political Question", $79 \mathrm{Nw}$ U L Rev 1031 (1984/85); Wayne McCormack, The Justiciability Myth and the Concept of Law, 14 Hast Con L Q 595 (1987); Lee A. Albert, Justiciability and Theories of Judicial Review: A Remote Relationship, 50 S Cal L Rev 1139 (1977). For an earlier and somewhat more limited position, see Fritz W. Scharpf, Judicial Review and the Political Question: A Functional Analysis, 75 Yale L J 517 (1966). The impulse to eliminate exceptions to judicial review can also be seen in appreciation for judicial protection of the Tenth Amendment following the Supreme Court's decision in Garcia, 469 US 528. See, for example, William W. Van Alstyne, The Second Death of Federalism, 83 Mich L Rev 1709 (1985); Martin H. Redish and Karen L. Drizin, Constitutional Federalism and Judicial Review: The Role of Textual Analysis, 62 NYU L Rev 1 (1987).

47 Henkin, 85 Yale L J 597 (cited in note 46).

48 Id at 622. 
consider ... an allegation that the political branches have acted illegally."49

The desire to minimize any exception to Marbury could always be seen in most of the academic commentary on the political question doctrine and, indeed (as I have suggested), it can be seen in the very words "political question doctrine." For Henkin, however, the objective is to eliminate, not minimize, any exception to judicial review. While earlier writers like Gunther and Wechsler attacked conceptions of the political question doctrine that undermined special criteria of lawfulness, Henkin takes it as a given that political considerations are incorporated into substantive doctrine and he uses this fact to extend judicial supervision. For Henkin the objective is not so much legal oversight as it is judicial oversight.

Henkin's argument suggests that as legal judgment becomes less distinct from political decision, exceptions to Marbury become more intolerable. Why should that be so? Henkin's answer is that the strongest arguments for the political question doctrine came from progressives who saw judicial restraint as a prerequisite to social reform. However:

Since Frankfurter and Black wrote, judicial review has had a new birth, its character and content reformed, and its place established as a hallmark of American political life. ... I see no place in it for an exemption for certain "political questions."

Eliminate political questions, then, because judges have become a force for good; it is at least worth having them consider every claim on the merits. Judges are to be trusted, Henkin believes, if we can force them to listen.

In The Least Dangerous Branch, Bickel argued strenuously that forcing judges to listen when the timing or issue was wrong would only lead to unfortunate decisions on the merits; better to avoid the merits through the political question doctrine than to stunt political discourse by teaching such lessons as that racially segregated facilities could be equal. ${ }^{51}$ But Plessy ${ }^{52}$ was long before the judiciary's "new birth." If Henkin is right that the purpose of judicial review is enlightened politics and that modern judges can be trusted to be progressive, then exceptions to Marbury become

\footnotetext{
49 Id at 623 .

so Id at 625 .

s1 Bickel, The Least Dangerous Branch at 71, 197, 240 (cited in note 12).

s2 Plessy v Ferguson, 163 US 537 (1896).
} 
even less tolerable than they had been to the legalistic critics of Bickel. The devotion of the legalist to judicial review is exceeded only by the devotion of the optimistic reformer.

Bickel's idea that the foundation of constitutional law is politics was certainly linked to progressive political objectives ${ }^{53}$ but was too serious to be limited by them. If law should be informed by political experience then, he argued, the law of equal protection must be informed by the southern resistance that he abhorred. ${ }^{54}$ For Bickel, judges were not to be trusted always to hold to constitutional ideals but neither were they to be entirely trusted when they did hold to those ideals. Hence, he invited the participation of wider, nonlegal communities in the formation of constitutional meaning. For Henkin, progressive political outcomes are the objective and they are more likely if the political question doctrine is obliterated - that is, if those wider communities are excluded from the decision, while matters of degree and expedience are folded into normal legal discourse. These differences are reflected in each writer's manner of expression. Although Bickel ostensibly wrote about technical legal subjects, his style was robustly political-eloquent, ambivalent, contradictory, inquiring. In contrast, Henkin's idea that the purpose of judicial review is progressive politics comes wrapped in the expository style of a high-quality brief-uncompromising, detailed, focused, and technical. If our objectives are to be reform and judicial oversight rather than principle, at least we will keep the old forms. Whether or not there is law, it is lawyers who are doing the talking.

Lawyers make arguments, and Martin Redish makes the argument that the political question doctrine should "play no role whatsoever." He rejects every justification for the doctrine that he can find, including not only the various prudential arguments but also the legalistic position that some constitutional provisions vest enforcement power in a nonjudicial branch. Redish, like Henkin, would allow many of the factors used to identify political questions to influence decisions as long as they influence the substance of a court's interpretation. Thus, although he criticizes the "absence of judicially discoverable standards" rationale, Redish would permit a finding that a constitutional provision is so empty as not to bear on a particular issue. ${ }^{56}$ Similarly, although he argues

\footnotetext{
${ }^{53}$ Bickel, The Least Dangerous Branch at $242-43$ (cited in note 12).

s4 Id at 263-65.

${ }^{35}$ Redish, 79 Nw U L Rev at 1033 (cited in note 46).

se Id at 1048.
} 
that a court should not avoid decision because of the risk of noncompliance, courts can take into account claims of necessity or emergency. ${ }^{57}$ Like Henkin, then, Redish's objective is to insist on review, not to insulate legal decision from "political" determinations about matters of fact, expedience, or degree. Henkin's stance, however, is optimistic. His concern is to extend the benefits of judicial oversight to the few, exceptional areas that are still thought to be exempt. Redish's stance, on the other hand, is defensive, and his concern is to rebut a set of arguments that (absurdly) would threaten all of judicial review.

Redish argues, for instance, that even the "classical" view of political questions has unacceptably wide implications. ${ }^{58}$ If it is conceded that the Guarantee Clause ${ }^{8 \vartheta}$ is to be interpreted by Congress, then it would be possible to conclude that all authorizations in the Constitution to the legislative and executive branches create exceptions to Marbury. Every such authorization names a nonjudicial branch as having a constitutional responsibility and no such authorization mentions judicial oversight. Similarly, since there is no intrinsic reason for judicially manageable standards to exist in any special way for any provision, this criterion, too, would prove too much. ${ }^{60}$ It would, that is, threaten all of judicial review. As Redish says,

If in certain instances the Court abdicates this responsibility, it becomes logically difficult to distinguish the majority of cases in which the Court deems legitimate the exercise of its review power. ${ }^{61}$

The possibility that most or even all constitutional questions are political had been lying in wait ever since the Baker Court abandoned formal categories and plunged into the indeterminacy of functional analysis. ${ }^{62}$ By 1985 Redish could treat this possibility as a trump rather than as a threat. For him, any idea that could significantly limit the power of judicial review should, for that reason, be rejected. The danger that some saw in Bickel's thinking-the politicizing of the sources and purposes of constitutional law-was for Redish a source of impatience. Because constitutional law is obviously and inescapably political, the political question

\footnotetext{
${ }^{37}$ Id at $1048,1050-52$.

ss Id at 1040-42.

so US Const, Art IV, § 4.

so Redish, $79 \mathrm{Nw}$ U L Rev at 1047 (cited in note 46).

61 Id at 1060.

-2 See text accompanying notes 14-17.
} 
doctrine should be abandoned. Only if some limited category of non-political constitutional law could be defined, might the political question doctrine be consistent with the scope of the authority of the Court that Redish finds axiomatic. Redish's argument has a peevish tone, for by now it seems so clear that the judiciary is the primary source of constitutional meaning and that a serious political question doctrine would cover virtually all constitutional issues. There is for Redish no reason to fear an idea with this absurd implication and every reason to abandon it.

Current irritation with the political question doctrine is, in sum, a reflection of the merger of law and politics. Although as recently as 1973, the idea of distinctively legal determinations had not seemed absurd to the editors of Hart and Wechsler, now-barely sixteen years later-the matter appears to be settled, not only for writers like Henkin and Redish, but for most of the academy. This is not to deny that some important scholars are still committed to principles in adjudication. Some are, but they write as holdovers from an earlier period or as dissenters. Even Ronald Dworkin's extended (and increasingly qualified) defense of principle ${ }^{63}$ only proves the point, for today the idea of a forum of principle seems so unlikely to so many that a reputation for brilliant and audacious argument can be built around it.

It would be a protracted undertaking to demonstrate fully the massive change that has taken place in shared beliefs about the nature and sources of public law. So complete is the triumph of politicized judging, however, that such a demonstration is not necessary. Everyone can see it. Although the change is pervasively evident in everyday judicial opinions and scholarly commentary, one event highlights the completeness of the transformation. In 1987, almost 2,000 law professors-reportedly 40 percent of the total-announced their opposition to the confirmation of Robert Bork as a Justice of the Supreme Court. ${ }^{64}$ This unprecedented eruption of scholarly opposition to a concededly able, learned, and experienced nominee can only be explained-unless Shelley $v$ Kraemer, Griswold v Connecticut, and Roe $v$ Wade are well-reasoned opinions-on the ground that for most law professors (as, unsurprisingly, for most Senators) results matter more than

${ }^{83}$ Ronald Dworkin, Taking Rights Seriously (Harvard, 1977); Ronald Dworkin, Law's Empire (Harvard, 1986).

34 Nomination of Robert $\mathrm{H}$. Bork To Be Associate Justice of the Supreme Court of the United States, Hearings Before the Committee On the Judiciary, U.S. Senate, 100th Cong, 1st Sess 3349-3412 (1987). 
reasons.

The emergence of political judging as a normal and inevitable practice is roughly coincident with the period between the publications of the second and third editions of Hart and Wechsler. Why has this change in the judicial function become complete so many decades after the intellectual successes of the legal realists and so many years after the moral successes of the Warren Court? Why was it fully achieved only toward the end of the period of the Burger Court?

IV.

Perhaps because the new Burger Court Justices were nominated by Republican Presidents and because conservative political rhetoric surrounded their appointments, the legal academy has only reluctantly and partially faced up to the central import of the Court's performance over the last fifteen years. ${ }^{65}$ That import can be stated simply: Building from the moral adventurism of the Warren era, the Burger Court systematically increased the scope and degree of judicial supervision over public policy. Consider the record. It was not until 1971, beginning with an opinion written by Chief Justice Burger, that racial classifications were approved for use in school desegregation remedies and that judicial management of school systems began to become nationwide. ${ }^{66}$ The judicial program of monitoring the kinds of public aid furnished to parochial schools also began in 1971 (again, with an opinion by Chief Justice Burger).$^{67}$ In that same year the Court, in a decision written by that same author, initiated serious, sustained judicial review of governmental use of sexual classifications. ${ }^{68}$ The theory of the "conditions of confinement" lawsuit, under which prisons in most of the states have been governed by injunctions, was first approved authoritatively in $1978 .^{69}$ The Burger Court not only created the right to abortion but also extended that right into areas such as parental notification and informed consent, that are deeply problematic even in terms of the original legal right enunciated by the

6s See Vincent Blasi, ed, The Burger Court, The Counter-Revolution That Wasn't (Yale, 1983). See also Albert W. Alschuler, Failed Pragmatism: Reflections on the Burger Court, 100 Harv L Rev 1436 (1987); Gene R. Nichol, Jr., Book Review, 98 Harv L Rev 315 (1984).

os Swann v Charlotte-Mecklenburg Board of Education, 402 US 1 (1971).

67 Lemon v Kurtzman, 403 US 602 (1971).

68 Reed $v$ Reed, 404 US 71 (1971).

Bo Hutto v Finney, 437 US 678 (1978). 
Court. ${ }^{70}$ It largely created the modern doctrine of procedural due process, under which the decision making methods of school principals, prison disciplinary boards, Social Security administrators, and university tenure committees are subject to judicial oversight. $^{71}$ It was the Burger Court that extended free speech protections to corporations and prisoners, that defined advertising and exotic dancing and money as speech, that prohibited patronage dismissals, and that protected defamatory speech about private individuals. ${ }^{22}$ The Burger Court played a major part in bringing down a President by ordering the disclosure of records of confidential conversations with his assistants. ${ }^{73}$ It subsequently applied the newly invigorated principle of separation of powers to invalidate, in effect, hundreds of federal statutes containing legislative veto provisions as well as much of the Federal Election Campaign Act of 1971 and the Emergency Deficit Control Act of $1985 .^{74}$ In a meandering string of opinions, it undertook detailed supervision over death penalty legislation ${ }^{75}$ and, potentially, over sentencing laws as well. ${ }^{76}$ And the Burger Court extended many established principles in new and uncertain directions: the prohibition against racial discrimination was applied for the first time to limit peremptory jury challenges; ${ }^{77}$ the one person one vote rule was reshaped to allow judicial supervision of political gerrymanders;" the "dormant commerce clause" was revived and applied creatively; ${ }^{79}$ and both the Takings and the Contracts Clauses were used in new and poten-

${ }^{70}$ Roe v Wade, 410 US 113 (1973); Bellotti v Baird, 443 US 622 (1979); Thornburgh v American College of Obstetricians and Gynecologists, 476 US 747 (1986).

7 Goss $v$ Lopez, 419 US 565 (1975); Wolff $v$ McDonnell, 418 US 539 (1974); Mathews $v$ Eldridge, 424 US 319 (1976); Perry v Sindermann, 408 US 593 (1972).

72 First National Bank v Bellotti, 435 US 765 (1978); Procunier v Martinez, 416 US 396 (1974); Virginia State Board of Pharmacy v Virginia Citizens Consumer Council, 425 US 748 (1976); Schad v Mount Ephraim, 452 US 61 (1981); Buckley $v$ Valeo, 424 US 1 (1976); Elrod v Burns, 427 US 347 (1976); Gertz v Robert Welch, Inc., 418 US 323 (1974).

${ }^{73}$ United States $v$ Nixon, 418 US 683 (1974).

74 INS v Chadha, 462 US 919 (1983); Buckley v Valeo, 424 US 1 (1976); Bowsher $v$ Synar, 478 US 714 (1986).

${ }^{75}$ Furman v Georgia, 408 US 238 (1972); Gregg v Georgia, 428 US 153 (1976); Proffitt v Florida, 428 US 242 (1976); Jurek v Texas, 428 US 262 (1976); Woodson v North Carolina, 428 US 280 (1976); Roberts $v$ Louisiana, 428 US 325 (1976); Eddings v Oklahoma, 455 US 104 (1982); Pulley v Harris, 465 US 37 (1984); McCleskey v Kemp, 481 US 279 (1987).

${ }^{78}$ Solem v Helm, 463 US 277 (1983).

77 Batson v Kentucky, 476 US 79 (1986).

78 Davis v Bandemer, 478 US 109 (1986).

7 Philadelphia v New Jersey, 437 US 617 (1978); Hunt $v$ Washington State Apple Advertising Commission, 432 US 333 (1977); Kassel v Consolidated Freightways Corp., 450 US 662 (1981). 
tially far-reaching ways. ${ }^{80}$ Even those decisions in which the Court reduced judicial influence are characterized by qualifications or uncertainties that distinctly hold open the possibility of subsequent re-entry, and in important instances judicial power has eventually expanded after initial withdrawal. ${ }^{81}$

Given this record, it is accurate but incomplete to condemn the Court for doctrinal inconsistency or for lack of uplifting vision. It is distorting to seize on those areas in which the Court might have gone further than it did and then to focus on its caution. It is myopic to emphasize only those few areas of actual retreat, such as standing and the exclusionary rule. Now that the era of Chief Justice Burger is receding into the past, it is time to acknowledge that his Court did have a central theme. Its theme was the extension of undefined judicial oversight (and the potential for detailed judicial intervention). Under the Burger Court, the core objective of judicial review became judicial review.

Expanding the scope of judicial supervision required the assumption that the availability of relevant legal standards was a matter of volition and experimentation rather than of the intrinsic nature of the subject matter. In turn, the Court's behavior appeared to validate the assumption, for an ever widening array of unmistakably political issues became the customary stuff of constitutional adjudication. Although individually they seem unexceptional, it is worth a moment to recall the kinds of issues that we have come to expect the federal courts to resolve: At what point does the cost of busing school students for the purpose of achieving school desegregation become excessive? What would be the marginal deterrent effect on unlawful police conduct of extending the exclusionary rule to grand jury proceedings? How important to the executive function is the candid advice of Presidential aides? (And what is the likely effect on the quality of such advice if there is a risk of disclosure to the judiciary of the content of Presidential

so Nollan v California Coastal Commission, 483 US 825 (1987); United States Trust Company v New Jersey, 431 US 1 (1977); Allied Structural Steel Co. $v$ Spannaus, 438 US 234 (1978).

:2 Areas where withdrawal has been uncertain and where re-entry is possible include standing (see, for example, Gene R. Nichol, Jr., Injury and the Disintegration of Article III, 74 Cal L Rev 1915 (1986)), and the Tenth Amendment (see for example, Andrzej Rapaczynski, From Sovereignty to Process: The Jurisprudence of Federalism After Garcia, $1985 \mathrm{~S} \mathrm{Ct}$ Rev 341). The clearest example of expansion after withdrawal is school desegregation. Compare Milliken v Bradley, 418 US 717 (1974), with Milliken v Bradley, 433 US 267 (1977), and Hills $v$ Gautreaux, 425 US 284 (1976); compare Dayton Board of Education v Brinkman, 433 US 406 (1977), with Dayton Board of Education v Brinkman, 443 US 526 (1979), and Columbus Board of Education v Penick, 443 US 449 (1979). 
conversations?) What sex roles should now be considered outdated? Is family life strengthened by requiring a minor female to get her parents' consent before undergoing an abortion? How likely is it that the introduction of procedural safeguards into prison disciplinary decisions will increase disrespectful or violent behavior of prisoners? Is the moral significance of protecting the potential lives of the unborn greater in the sixth month of pregnancy than the seventh? Is a woman's privacy interest in her pregnancy greater in the third month of pregnancy than in the fourth? How important to military discipline are uniforms? At what point does a political gerrymander deny to members of a continually losing political party a fair chance to influence the political process? Is the principal effect of providing maps to parochial schools religious or educational? Do restrictions on price advertising strengthen pharmacists' professional status? Is conditioning parents' re-marriage on proof of ability to support noncustodial children an effective way to ensure financial support for those children? What kind of public debate over governmental support for religious schools is tolerable in our political system? Are group deliberations significantly better in twelve-person juries as compared to six-person juries? (In six-person juries as compared to five-person juries?) What mix of burdens and benefits imposed on the states by federal legislation indicates a failing of the national political process?

Such questions, which could be multiplied almost endlessly, have been important in the resolution of constitutional cases under the Burger Court. Some are empirical and predictive; some involve the interpretation of political and social history; some are profoundly moral and aspirational; some are matters of degree; some involve the internal functioning of the executive or legislative branches; some require knowledge of partisan politics; and some can be answered only by reference to some political, economic, sociological, or psychological theory. They are not legal questions. Traditional legal materials (text, intent, precedent) and traditional legal methods (adversarial fact-finding, analogical reasoning, principled explanation) are insufficient-indeed, sometimes irrelevant-to answering them. They are political questions in the sense that people without training or experience in law certainly possess knowledge and judgment useful for answering them. Of course, like everyone else, judges can try to answer them. But when judges enter what Thayer called "the region of political administration," they must either impose legalistic methods on problems that are at most partially legal or they must adopt the concerns and method- 
ologies of nonlawyers. ${ }^{82}$ In either event, judges' decisions tend to lose authoritativeness.

The claim that there is no distinctively legal quality to the sorts of questions now ordinarily essential to deciding constitutional cases is, I think, not contentious or even seriously doubtful. The point is at least implicit in the outpouring of theories-about the nature of the adjudicatory process, the position of the judiciary in the political system, and so on-that attempt to provide some reason to believe that federal judges are especially entitled to answer the sorts of questions they now decide. If there is any urge to deny the political character of our public law it arises largely because we have become so accustomed to courts making such judgments. The Court and most of the rest of us have come to regard political questions as legal questions because that is a convenient (perhaps necessary) precondition to maintaining or extending the scope and scale of judicial supervision of public policy. This obliteration of any characteristically legal aspect to constitutional questions (except, of course, for the institutional source of the authoritative answers to those questions) is the legacy of the Burger Court.

This legacy does not mean that courts now make constitutional decisions in the same way or on the basis of the same considerations as would political institutions. To some extent, of course, they do-as, for example, when judges rely on political instinct or fashionable morality or institutional self-interest. But judges usually convert political questions into a form that is familiar to lawyers. ${ }^{83}$ For example, they decide whether an urban school system should be left racially imbalanced or re-shaped "root and branch" on the basis of a comfortingly "adjudicative" finding about the past behavior and intent of specific individuals. ${ }^{84}$ For many years, the Court narrowed the problem of gerrymandered legislative districts to a matter of numerical equality. ${ }^{85}$ It resolved the complex issues raised by legislative veto provisions largely by reference to some constitutional text. ${ }^{86}$ This sort of conversion is not found only in highly visible, adventurous areas of constitutional adjudication. The potentially broad question whether a tax

82 Thayer, 7 Harv L Rev at 152 (cited in note 41).

ss For a prophetic assertion of this point, see Lon L. Fuller, The Forms and Limits of Adjudication, 92 Harv L Rev 353, 404 (1978).

*4 See, for example, Keyes v School District No. 1, Denver, Colo., 413 US 189 (1973).

${ }^{85}$ Dean Alfange, Jr., Gerrymandering and the Constitution: Into the Thorns of the Thicket at Last, 1986 S Ct Rev 175, 176.

${ }^{86}$ INS v Chadha, 462 US 919 (1983). 
is "fairly related" to the services provided by a state has been converted to a more legalistic sounding question regarding whether the level of the tax is "reasonably" related to taxpayer contact with the state. ${ }^{87}$ Indeed, virtually all constitutional decisions are explained on the basis of standards, doctrines, and precedents that are (or used to be) foreign to normal political deliberations. But all this legalistic paraphernalia either subsume the broader issues on which judges have no special knowledge or exclude highly relevant considerations. $^{88}$ The fact that it has been possible to find, construct, or imagine the possibility of judicially manageable standards does not alter the political nature of underlying constitutional questions.

While the ostensible purpose of constitutional adjudication remains the resolution of particular cases and the normal intellectual method remains doctrinal, the Burger Court has made it undeniable-indeed, it seems normal and inevitable-that the subject matter is political. As a consequence, a radical disjunction has developed between the Court's methodology and the kinds of objectives that modern academic commentators attribute to its decisions. It is simply no longer plausible to justify complex regimes of judicial regulation as the outcome of the application of principles and doctrines. The setting and style is still legalistic (lawyers are doing the talking), but since the substance and effect are political, it is now obvious that the objective must be political. Hence, in recent years much theoretical work is aimed at re-conceptualizing the federal judiciary's function. If our received notions of lawfulness-the faithful adherence to external authority, the rigorous use of neutral principles, the timely termination of specific disputes, and so on-are too narrow for the tasks that the courts are doing every day, then perhaps our concept of legality must change. Bickel's critics, in this respect, were ahead of their time.

\section{V.}

Efforts to re-conceptualize the federal judicial function include well-known proposals that constitutional decisions should unblock the democratic process ${ }^{89}$ and that judicial remedies should prospectively shape and improve the bureaucratic operation of public

${ }^{87}$ Stephen F. Williams, Severance Taxes and Federalism: The Role of the Supreme Court in Preserving A National Common Market for Energy Supplies, 53 U Colo L Rev 281, 287-89 (1982).

${ }^{88}$ See Thayer, 7 Harv L Rev at 135 (cited in note 41).

80 John Hart Ely, Democracy and Distrust (Harvard, 1980). 
institutions..$^{90}$ However, perhaps the most common type of modern justification casts the Court as teacher to the rest of society. Writing before the era of the Burger Court, Bickel had proposed a similar objective, but his proposal was linked to a distinctive idea of lawfulness. Bickel wanted the Court to teach principles, to hold out uncompromised ideals that transcended both immediate consequences and tragic political practicalities. This task, while risking the error of abstraction, was thought to be worthwhile, at least if the Court would draw upon political experience in deciding on both timing and content. In contrast, the didactic functions suggested by theorists of the Burger Court era are more equivocal. The benchmark now is regulatory supervision, a function that is based on distrust of politics and dissatisfaction with normal political outcomes and thus is inconsistent with using political life as a source of constitutional meaning. Moreover, a broadly supervisory judicial role requires or, at least, results in a complex pattern of decisional outcomes and explanations. As the Court limits, qualifies, and prescribes, its rulings lose any capacity they might have had to communicate unblemished ideals or unqualified principles. Thus the theorists writing in the Burger Court era are forced to infer subtle, vague lessons from long, enigmatic lines of cases.

It is difficult to draw a central lesson even from the Court's most visible and morally compelling line of cases, the school desegregation decisions. What is the public to make of a set of decisions that first demands nondiscriminatory attendance policies and then invalidates both parental choice and neighborhood school policies? What ideal is reflected in decisions that begin by emphasizing that policies of racial exclusion do psychological and educational harm to individual students and end by mandating educational changes for the benefit of students born long after the commission of the illegal exclusionary acts? Where is the principle in decisions that impose significant costs on both defendants and plaintiffs in an effort to avoid racially imbalanced schools, while the Court repeatedly affirms that even wholly black or white schools are constitutional? And what concept of justice can emerge from a remedial regime when the measure of correction (some specific percentage of racial mixture) is arrived at by conjecture and bears little relation to the quality of the education provided the plaintiff class? To ask these questions is not to imply that there are no answers, but to suggest why the answers are not simple or clear.

${ }^{\circ}$ Fiss, 93 Harv L Rev 1 (cited in note 36). 
Paul Gewirtz, for example, has made a serious and useful effort to understand the post-Brown cases. He concludes that the desegregation cases as a whole embody the "corrective ideal."91 This ideal "may be as much a viewpoint as an analytic tool."92 It does not tell us what we should do, but it "insists upon an imagery":

The images are rooted in the past-the awful, deliberate wrongs inflicted on black people for so long, the brutal sweep of continuity between past deeds and present life. From that image of wrong comes the commitment to correction, the distinctive dynamic of racial justice. The corrective idea . . . affirms that, because of the past, the claims of black Americans are unique and uniquely just. It affirms, at the very least, a way of thinking about racial justice. ${ }^{93}$

It does not deprecate the subtlety of Gewirtz's analysis or the importance of the lessons he draws from the desegregation cases to note that the corrective ideal is a highly generalized "way of thinking." Generality, complexity, and vagueness are to be expected when communicative import must be inferred from the detail of cases that represent protracted efforts to cope with the nuance and difficulty of political circumstance.

Romanticism, therefore, has become characteristic of scholarly commentary on the meaning of the Court's decisions. Robert Burt finds in the desegregation decisions a "dramatization" of the lessons of Christ's parables. ${ }^{94}$ The "pedagogic technique" of the race cases is:

first to command the attention of people who conceive themselves as safely inside some protective flock; then to persuade these people that they are no different from others visibly outside ... and, finally, having provoked in these once-smug insiders feelings of vulnerability ... to show how this empathy . . can serve as a route for membership in a community. . . ${ }^{95}$

Such thinking is not restricted to the extraordinary area of school desegregation. Lee Bollinger proposes that the Court's free speech

${ }^{91}$ Paul Gewirtz, Choice in the Transition: School Desegregation and the Corrective Ideal, 86 Colum L Rev 728 (1986).

82 Id at 798.

93 Id.

94 Robert A. Burt, Constitutional Law and the Teaching of the Parables, 93 Yale L J 455, 464-66 (1984).

${ }^{25}$ Id at 478. 
decisions should be read as a validation of the psychological trait of tolerance:

At this stage in our social history ... free speech involves a special act of carving out one area of social interaction for extraordinary self-restraint, the purpose of which is to develop and demonstrate a social capacity to control feelings evoked by a host of social encounters. ${ }^{96}$

Philip Bobbitt writes of the "expressive function" of the Court and says that the overruling of precedent "can inform and lead into new places the flow of our sympathetic consciousness and can lead our sympathy away in recoil from things that are dead."9z Michael Perry refers to a "constitutional dialogue between the Court and the other agencies of government-a subtle, dialectical interplay [on moral issues]." A8 Abram Chayes speaks of "the discourse of justice":

[T]he Court does not seek to persuade bureaucrats or legislators or even voters about immediate responses to particular programs or crises. It speaks to all of us . . . about the basic values that define us as a nation and a society. It seeks to persuade us at the deepest and most fundamental level. ${ }^{99}$

In short, much of the most insightful commentary that has grown up during the Burger Court period flees from the coercive operational detail of the cases to the high plane of political conversation and large values.

Since the primary consequence of the Burger Court has been to extend the influence of federal judges, there can be little doubt that the Court has been engaged in some kind of dialogue with the American people. It is at least doubtful, however, that the conversation has been at quite the level that sophisticated readings of long lines of cases would suggest. The public at large is less likely than are scholars to expend the intellectual energy necessary to shape complicated and apparently contradictory cases into a coherent whole. The public is less likely to be engrossed by subtle shadings in the opinions and more likely to be affected by the im-

${ }^{96}$ Lee C. Bollinger, The Tolerant Society: Freedom of Speech and Extremist Speech in America 10 (Oxford, 1986).

${ }^{97}$ Philip Bobbitt, Constitutional Fate: Theory of the Constitution 189 (Oxford, 1982). 1988).

98 Michael J. Perry, Morality, Politics, and Law: A Bicentennial Essay 178 (Oxford,

9 Abram Chayes, How Does the Constitution Establish Justice? 101 Harv L Rev 1026, 1041 (1988). 
mediate, visible consequences of the decrees. And, because the ramifications of constitutional law now so frequently reach down into the daily working lives of teachers, police, reporters, social workers, and homemakers, it is to be expected that the Court's vocabulary is gradually spreading and is increasingly shaping the thinking of nonlawyers. School students talk about due process, prisoners about the right to access, editorialists about malice, school board members about content discrimination, and parents about their children's right to privacy. In the last few years United States Senators have begun to engage judicial nominees in lengthy discussions about stare decisis, historicism in constitutional interpretation, standing, reverse incorporation, and the three tiers of equal protection scrutiny. ${ }^{100}$ It is true, then, that the Court is teaching. Whatever its other lessons may be, the Court is teaching the rough lessons of coerced behavior and the intellectual lessons of doctrinal thinking. It is teaching people to act and to think legalistically about political issues.

In the last eighteen years, it has come to seem altogether normal that federal courts should resolve issues that have no distinctively legal quality and that the judicial function should be thought of as political conversation. Both of those norms are a product of the Court's commitment to a general supervisory role and its immersion in wide-ranging programs of social regulation. The Burger Court politicized judging as it legalized politics. It accomplished wholesale what Bickel imagined at the margin and it made a fact of what his critics feared.

\section{CONCLUSION}

In 1989, the political question doctrine is largely incomprehensible to the Court and to the academy. It is incomprehensible because the idea of law is now largely incomprehensible. Bickel's treatment of political questions was once thought subversive, but a mainstream Republican Court has established two of his principal ideas: that all constitutional issues have broad political aspects and that the function of the federal judiciary in constitutional cases is political education.

Since both constitutional content and judicial function are now political, the political question doctrine, as an exceptional category, seems ripe for discarding. But these same developments explain why the political question doctrine threatens to widen and to

${ }^{100}$ See Robert F. Nagel, Advice, Consent, and Influence (forthcoming, Nw U L Rev). 
swallow much of the judicial machinery that now sits so confidently above it. If the meaning of the Constitution is properly determined on the basis of nonlegal considerations, the wide realm of political life that is appropriate to shaping that meaning cannot be forced into a narrow legal category. Having established so much of Bickel's thought as fact, the Supreme Court in the years ahead will have to grapple with another of his fundamental ideas, the idea that politics should be the norm and judging the exception.

The conventional reason for confining the arena of judicial decision making was the belief that only some defined class of public policy issues could be satisfactorily governed by the unembarassed application of legalistic resources and norms. If such a category exists, the Burger Court helped us to forget what it is. On the other hand, as Bickel's more disquieting passages suggest, perhaps there never were any distinctively legal questions. If not, the sense (which was widely shared until recently) that such questions did exist might have been based on nothing more than the associations built up by recurrent application of legal methods in certain areas. The costs of this continued resort to law could be kept acceptable because judicial power was exceptional. The question is: as the range of judicial power is narrowed, will any plausible category of legal questions emerge? 
